\title{
Farmer adoption of pasture renewal practices: the influence of credible information sources
}

${ }^{1}$ AgResearch Limited, Lincoln Research Centre, Cnr Springs Road \& Gerald Street, Private Bag 4749, Christchurch 8140, New Zealand. ${ }^{2}$ Wageningen University, Knowledge Technology and Innovation Group. PO Box 8130, 6700EW Wageningen. The Netherlands

wei.yang@agresearch.co.nz

\section{Abstract}

Effective pasture management in the dairy sector is supported by the pasture renewal practices (PRPs) undertaken by farmers. However, the rate and extent of adoption of PRPs by farmers is influenced by their attitudes toward pasture renewal. The aim of this paper was to help the understanding of drivers and barriers that could be derived from the investigation of farmer attitudes to pasture renewal, and to relate credibility of information sources to their perceptions of pasture renewal. A two-step process was applied to existing survey data of dairy farmers in the Waikato and Bay of Plenty regions of New Zealand. First, a factor analysis clustered the dairy farmers into different groups based on their attitudes to pasture renewal. The results show that satisfaction with previous pasture renewal experiences was an important factor affecting farmer adoption. Second, the results from a correlation analysis between the different clusters, indicates that information from local experts and farmers was valued the most by all groups as they were perceived to be the most credible. Motivated farmers also tended to seek guidance from credible publications and websites.

Keywords: pasture renewal, dairy farmers, information credibility, factor analysis

\section{Introduction}

New Zealand's temperate climate makes it possible fo dairy farmers to gain the benefits of continual pasture growth that provides an inexpensive and sustainable feed supply (Tozer et al. 2015). However, grazed pasture systems are dynamic and continually changing in quality and quantity. In addition to the overwhelming impact of climate, factors such as soil type, plant species, fertiliser use and grazing management, as well as pests and weeds, can affect the growth of pasture or cause it to deteriorate over time (Bewsell et al. 2008). Pasture renewal practices (PRPs), including full pasture renewal, pasture renovation, undersowing, and crop sequencing are common ways to improve pasture performance (Rijswijk \& Brazendale 2016).

The Waikato and Bay of Plenty are New Zealand's major dairying regions, where pasture growth has been constantly threatened by frequent droughts, pests and weeds (Tozer et al. 2015). As a result, dairy farmer have been dissatisfied with the performance an persistence of their pastures. Although pasture renewal has been regarded as the key source of nutritious and cost-effective feed (Bewsell et al. 2008; Rijswijk \& Brazendale 2016), farmers did not believe it would actually improve pasture persistence and performance (Rijswijk \& Rhodes 2015). For exampe, they were concerned that yields of modern cultivars realised in commercial plot trials may not be realised on a farm system scale (Tozer et al. 2015).

Many studies have focused on evaluating the benefits of pasture renewal and providing guidance for farmers to carry out good PRPs on their farms (Brazendale et al. 2011; Stevens \& Knowles 2011). However, literature on the exploration of farmer's adoption behaviour specifically regarding pasture renewal is limited (Belgrave et al. 1990; Rijswijk 2013; Rijswijk \& Brazendale 2016). The existing literature on adoption generally provides an insight into various factors that influence adoption by land owners (e.g. technology adoption, conservation practices an good environmental practices) (Pannell et al. 2006) These factors can be summarised by farmer attitudes to these practices, farm and household characteristics, and other contextual factors such as community and neighbourhood effects (Baumgart-Getz et al. 2012; Knowler \& Bradshaw 2007).

To facilitate farmer adoption of PRPs, understanding their satisfaction with and attitudes towards the practices is crucial, as well as the influence of the different farmer characteristics on adoption of PRPs. One of the contextual factors for farmer adoption is access to relevant and credible information as indicated by recent tudies (Pann ll et al. 2006; Hansson \& Fergason 2011; Rijswijk 2013; Yang \& Sh; 2017). It is also importan to know which factors are relevant to a cohort of farmer that will enhance the specialisation of programmes and projects supporting the adoption of PRPs

The purpose of this paper was to identify the factors affecting farmer adoption of PRPs, and specifically, the role of credible information sources in the adoption process. Three questions will be answered: 1) what are 


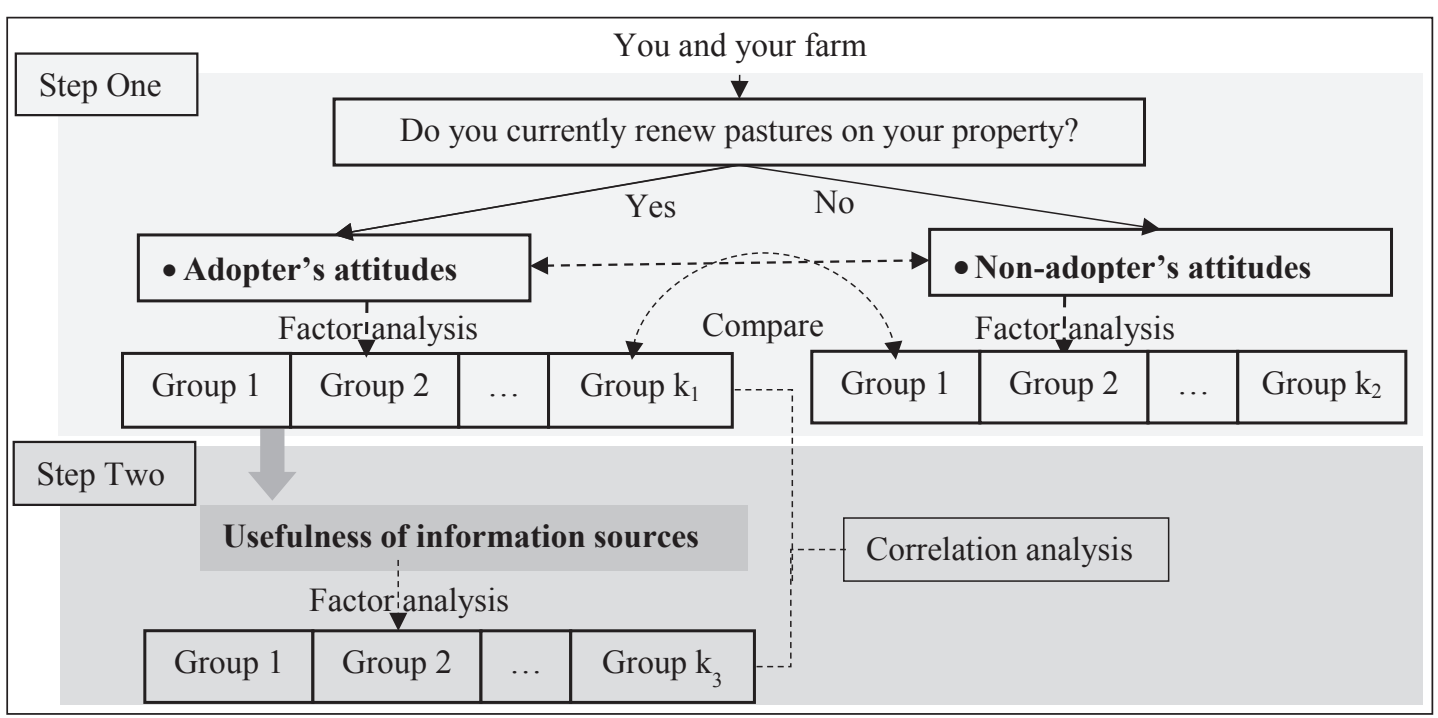

Figure 1 Conceptual analysis framework.

the drivers and barriers to the adoption of PRPs due to farmer attitudes? 2) to what extent are their attitudes homogeneous and 3) which information sources are associated with farmer attitudes to PRPs?

\section{Methods}

To understand farmer concerns about pasture renewal, two surveys of dairy farmers in the Waikato and Bay of Plenty regions were conducted in 2010 and 2015 (Rijswijk \& Rhodes 2015). These surveys aimed to raise awareness about pasture renewal, to identify barriers to adoption of current PRPs and to establish a dataset that can be used to evaluate interventions.

Using the survey data, Rijswijk \& Brazendale (2016) compared farmer confidence, satisfaction, and attitude to pasture renewal in 2010 and 2015. Results showed farmer perceptions and satisfaction levels associated with thir PRPs changed over importance of different information sources. Data for this study were drawn from the same dataset as that utilised by Rijswijk \& Brazendale (2016), where 1015 useable survey results were available. Rijswijk \& Brazendal (2016) presented descriptive results, whereas this study applied a statistical analysis and focused on farme clusters, according to the link between farmer attitudes and information sources used, and how this affects their choices to adopt PRPs. The original surveys consisted of several sections such as those describing demographic information, farmer attitudes to pasture renewal and satisfaction with their renewal practices, as well as the perceived usefulness of information sources. These sections were also analysed for this study.

A conceptual analysis framework (Figure 1) was used to answer the three questions raised in the previous section. The analysis consists of two steps; step one, questions one and two addressed factors PRPs. Here, all farmers were categorised into labelled groups based on their attitudes to pasture renewal by using a factor analysis process to check if the categorisation of farmers was consistent across the groups who had renewed pasture recently or in the gast 12 who bo fre past 12 who had not (the 'non-adopters'); step two, adopters were categorised into information groups based on their about pasture renewal. Lastly, a correlation analysis was used to understand the relationship between information sources and farmer attitudes. R-studio, a free and open source analysis software, was used to analyse the results.

\section{Results}

Factors affecting farmer adoption pastures in the 12 months preceding the surveys (Table 1). The average age of surveyed farmers was 50.7 years, with $88 \%$ being male. Owners or owner-operators 15 years of experience. There were no significantly different ( $P>0.05)$ che Thacters (Table 1) between adopters and non-adopters when comparing the mean values of four variables (age, gender, ownership, and farming experience)

The mean values of seven attitude questions (Table 1) provide some insights into the drivers and barriers for dairy farmers to adopt PRPs. Answers to these questions were scaled from 1 to 5 , where 5 represents 'strongly that influence farmer adoption and non-adoption of perceived usefulness of different information sources

Approximately $8.9 \%$ of dairy farmers had not renewed accounted for $69 \%$ of respondents, while $80 \%$ had over agree' with the variable description. The average value of each attitude variable could be regarded as an indicator of either a driver or barrier to renewing pastures. Thus, variables with a mean higher than 3 (3 being 'neutral') might be a driver, while those with a value lower than 3 might be a barrier'. For example, the adopters were more satisfied with their recent renewal practices (3.24) than the non-adopters (1.93). A t-test was used to test for the differences between the mean farmer attitudes to pasture renewal. Based on the P-value associated with the t-test, adopters and nonadopters attitudes to past experience in pasture renewal, pasture performance, and information accessibility was different. This indicates that these variables may affect farmer choices to renew or not renew.

Table 1 Overview of different farmer characteristics and attitudes between adopters and non-adopters.

\begin{tabular}{|c|c|c|c|c|c|c|c|c|}
\hline & \multirow[t]{2}{*}{ Variable Description } & \multicolumn{2}{|c|}{$\begin{array}{c}\text { All farmers } \\
(\mathrm{n}=1015)\end{array}$} & \multicolumn{2}{|c|}{$\begin{array}{c}\text { Adopter } \\
(\mathrm{n}=925)\end{array}$} & \multicolumn{2}{|c|}{$\begin{array}{l}\text { Non-adopter } \\
\quad(\mathrm{n}=90)\end{array}$} & \multirow[t]{2}{*}{ P-value } \\
\hline & & Mean & SD & Mean & SD & Mean & SD & \\
\hline \multicolumn{9}{|l|}{ Farmer characteristic } \\
\hline Age & Age of farmer, continuous variable. & 50.7 & 10.74 & 50.711 & 10.71 & 50.5 & 11.1 & $\mathrm{NS}^{1}$ \\
\hline Gender & $\begin{array}{l}\text { Dummy variable equal to } 1 \text {, if male; } \\
\text { otherwise, female. }\end{array}$ & 0.12 & 0.32 & 0.11 & 0.31 & 0.12 & 0.44 & NS \\
\hline Ownership & $\begin{array}{l}\text { Interviewee's relationship to farm, } \\
\text { categorical variables. } \\
\text { Coded as } 1 \text {, owner or owner operator; } \\
\text { coded as } 2 \text {, co-owner; coded as } 3 \text {, manager; } \\
\text { coded as } 4 \text {, sharemilker; coded as } 5 \text {, others. }\end{array}$ & 1.75 & 1.28 & 1.73 & 1.27 & 1.84 & 1.4 & NS \\
\hline Farming experience & $\begin{array}{l}\text { Years of farming experience, } \\
\text { categorical variables. } \\
\text { Coded as } 1, \text { less than } 1 \text { year; } \\
\text { coded as 2, } 1-5 \text { years; coded as 3, 6-10 years; } \\
\text { coded as } 4,11-1 \text { y years; } \\
\text { coded as } 5 \text {, more than } 15 \text { years. }\end{array}$ & 4.69 & 0.76 & 4.70 & 0.74 & 4.54 & 0.98 & NS \\
\hline Attitude (Scale 1-5) & $\begin{array}{l}\text { Answers were scale coded as ordinal variables } \\
\text { with the values from } 1 \text { to } 5 \text {, representing } \\
\text { 'strongly disagree', 'disagree', 'neutral', } \\
\text { 'agree', and 'strongly agree', respectively. }\end{array}$ & & & & & & & \\
\hline Financial return & $\begin{array}{l}\text { Convinced of financial return regarding } \\
\text { renewed pasture. }\end{array}$ & 3.09 & 1.51 & 3.04 & 1.48 & 2.99 & 1.73 & NS \\
\hline Time investment & $\begin{array}{l}\text { Renewing pastures justify the time } \\
\text { investment required. }\end{array}$ & 2.80 & 1.42 & 2.76 & 1.40 & 2.62 & 1.66 & NS \\
\hline Information accessibility & $\begin{array}{l}\text { Information can be accessed to ensure } \\
\text { the success of PRPs. }\end{array}$ & 2.89 & 1.43 & 2.85 & 1.39 & 2.14 & 1.62 & $P<0.001$ \\
\hline Satisfactory experience & $\begin{array}{l}\text { Recent experiences of pasture renewal } \\
\text { on farm have been satisfactory. }\end{array}$ & 3.29 & 1.58 & 3.24 & 1.51 & 1.93 & 1.83 & $P<0.001$ \\
\hline Pasture performance & Happy with current pasture performance. & 3.13 & 1.36 & 3.18 & 1.31 & 2.92 & 1.76 & $P<0.001$ \\
\hline Suitable farm system & Pasture renewal fits current farm system. & 2.54 & 1.53 & 2.46 & 1.51 & 2.47 & 1.76 & NS \\
\hline Suitable cultivar & $\begin{array}{l}\text { A suitable cultivar was available for the } \\
\text { farm/ property. }\end{array}$ & 2.93 & 1.46 & 2.88 & 1.42 & 2.03 & 1.62 & \\
\hline
\end{tabular}

${ }^{1} \mathrm{NS}=$ not statistically significant. $\mathrm{SD}=$ standard deviation of the mean.

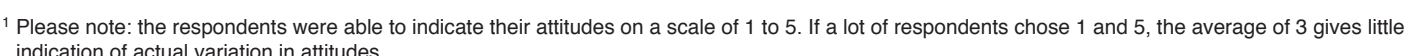

\section{armer attitudes to pasture renewal}

Based on the seven questions about farmer attitudes to pasture renewal (Table 1), a factor analysis (Principle Component approach) categorised farmer respondents into three different groups (Table 2), where those in each group share similar attitudes to pasture renewal, abelled as follows:

Management and investment orientated - these farmers appeared to perceive pasture renewal benefits from the perspective of appropriate farm system, time management and good financial returns. About $40 \%$ of farmers were strongly aligned with this group. Pasture performance oriented - this group of farmer focused on the performance of pastures. Good pasture performance may motivate them to adop .

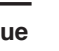
. 
PRPs. About $21 \%$ of dairy farmers were strongly aligned with this group.

- Information and experience oriented - knowledge and experience were highly valued by the farmers in this group. The availability of suitable cultivar was also strongly correlated with this group. About $39 \%$ of dairy farmers were strongly aligned with this group.

A sensitivity analysis was conducted using factor analysis to see if the categorisation of the groups was consistent across adopters and non-adopters (Table 2). Comparing the grouping results of the two subsets to those for all farmers, there was no significant differences in categorisation between the adopters and all farmers, but this was not the case for non-adopters. Thus, the categorisation for all farmers and adopters could no be utilised for non-adopters. Considering the limited number of non-adopters (90), more data may help for non-adopters and the understanding of their attitudes.

\section{Perceived usefulness of information sources}

Adopters were able to rate different information sources, such as on-farm consultants, contractors, scientists and internet. According to the ratings (scale 1-7) of information sources given by adopters, farmers were categorised into five groups (Table 3 ) using factor analysis; group labels were based on farmer evaluation of the usefulness of the information sources:

Local social networks: adopters in this group valued information and knowledge about pasture renewal from their local social networks, including farmers in the same district, farmer discussion groups and DairyNZ staff. Farmer discussion groups and DairyNZ staff are regionally oriented. The average rating from all adopters was 4.21 . About $27 \%$ of farmers were categorised in this group.

Publications and websites: this group of farmers regarded different types of publications and internet information most useful but the average rating score of 2.95 was low. Although a substitution effect
Table 2 Factor analysis of farmer attitudes to PRPs.

\begin{tabular}{|c|c|c|c|c|c|c|c|c|c|}
\hline & \multicolumn{3}{|c|}{ All farmers } & \multicolumn{3}{|c|}{ Adopters } & \multicolumn{3}{|c|}{ Non-adopters } \\
\hline & Group 1 & Group 2 & Group 3 & Group 1 & Group 2 & Group 3 & Group 1 & Group 2 & Group 3 \\
\hline & $\begin{array}{c}\text { Management } \\
\& \text { investment } \\
\text { orientated }\end{array}$ & $\begin{array}{l}\text { Pasture } \\
\text { performance } \\
\text { orientated }\end{array}$ & $\begin{array}{l}\text { Experience } \\
\text { \& information } \\
\text { orientated }\end{array}$ & $\begin{array}{c}\text { Management } \\
\& \text { investment } \\
\text { orientated }\end{array}$ & $\begin{array}{c}\text { Pasture } \\
\text { performance } \\
\text { orientated }\end{array}$ & $\begin{array}{c}\text { Experience \& } \\
\text { information } \\
\text { orientated }\end{array}$ & $\begin{array}{l}\text { Investment } \\
\text { orientated }\end{array}$ & $\begin{array}{l}\text { Farm system } \\
\& \text { pasture } \\
\text { oriented }\end{array}$ & $\begin{array}{c}\text { Experience \& } \\
\text { information } \\
\text { orientated }\end{array}$ \\
\hline $\begin{array}{l}\text { Financial } \\
\text { return }\end{array}$ & 0.85 & 0.09 & 0.32 & 0.87 & 0.09 & 0.30 & 0.87 & 0.28 & 0.33 \\
\hline $\begin{array}{l}\text { Time } \\
\text { investment }\end{array}$ & 0.85 & 0.13 & 0.36 & 0.83 & 0.14 & 0.40 & 0.88 & 0.31 & 0.24 \\
\hline $\begin{array}{l}\text { Information } \\
\text { accessibility }\end{array}$ & 0.46 & 0.16 & 0.67 & 0.44 & 0.18 & 0.68 & 0.49 & 0.16 & 0.58 \\
\hline $\begin{array}{l}\text { Satisfactory } \\
\text { experience }\end{array}$ & 0.28 & 0.00 & 0.84 & 0.32 & 0.04 & 0.81 & 0.23 & 0.14 & 0.85 \\
\hline $\begin{array}{l}\text { Pasture } \\
\text { performance }\end{array}$ & 0.16 & 0.96 & 0.07 & 0.14 & 0.96 & 0.05 & 0.22 & 0.93 & 0.15 \\
\hline $\begin{array}{l}\text { Suitable } \\
\text { farm system }\end{array}$ & 0.65 & 0.40 & 0.32 & 0.60 & 0.41 & 0.40 & 0.25 & 0.78 & 0.23 \\
\hline $\begin{array}{l}\text { Suitable } \\
\text { cultivar }\end{array}$ & 0.29 & 0.14 & 0.83 & 0.25 & 0.13 & 0.85 & 0.29 & 0.31 & 0.81 \\
\hline $\begin{array}{l}\text { Proportion } \\
\text { identified }\end{array}$ & $40 \%$ & $21 \%$ & $39 \%$ & $40 \%$ & $21 \%$ & $39 \%$ & $37 \%$ & $34 \%$ & $28 \%$ \\
\hline Method & & & & ar & ent analys & 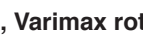 & ation'1 & & \\
\hline
\end{tabular}

Sample size

Test for
choosing

three factors

Total variance

explained by

$92.64 \%$

$91.04 \%$

$93.17 \%$

Note: shaded cells have loading on factors $>0.5$, indicating the threshold value for including the attitude as a key component in the group.

See Schmitt \& Sass (2011) for information on the Varimax rotation. between mail publication and websites was expected, farmers tended to value both sources, with $21 \%$ of farmers strongly aligned with this group.

- Contractors and fertiliser representatives: this group of farmers believe the most useful information came from contractors and fertiliser representatives, with $20 \%$ of farmers identifying strongly with this group. The average rating of the information sources in this group was 2.95

- Seed compaies information from seed retailers and companies (including highly with (arme in highly with farmers in this group scoring 4.65. About $19 \%$ of adopters were strongly aligned with this group.

Experts: farmers in this group had confidence (highest score of 4.88) in the knowledge and information obtained from experts including scientists, researchers and on-farm consultants. About 13\% of farmers were strongly aligned with this group.

Correlation analysis was used to identify if the classifications described in Tables 2 and 3 were related to each other-Adopters' scores for each of the different groups were estimated so that correlation analysis (of a be pefortion to identify if scores in one group (of information sources)

Limited correlation relationships existed betwee the groups (Table 4). All three attitude groups were

Table 3

\begin{tabular}{|c|c|c|c|c|c|c|}
\hline & & Group 1 & Group 2 & Group 3 & Group 4 & Group 5 \\
\hline & $\begin{array}{l}\text { Mean } \\
\text { Score }\end{array}$ & $\begin{array}{l}\text { Local } \\
\text { social } \\
\text { network }\end{array}$ & $\begin{array}{l}\text { Publication } \\
\text { \& website }\end{array}$ & $\begin{array}{l}\text { Contractor } \\
\text { \& Fertiliser } \\
\text { rep }\end{array}$ & $\begin{array}{l}\text { Seed } \\
\text { company }\end{array}$ & Expert \\
\hline On-farm consultant & 4.96 & 0.09 & 0.06 & 0.02 & 0.07 & 0.97 \\
\hline DairyNZ staff & 3.68 & 0.72 & 0.26 & 0.22 & -0.05 & 0.18 \\
\hline Other farmers in the same district & 4.75 & 0.77 & 0.02 & 0.14 & 0.02 & -0.02 \\
\hline Farmer discussion group & 4.21 & 0.85 & 0.07 & 0.09 & 0.04 & 0.02 \\
\hline Seed merchant/ retailer & 4.76 & 0.12 & -0.01 & 0.19 & 0.79 & 0.18 \\
\hline Catalogues from seed merchants/ seed companies & 4.54 & 0.0 .04 & 0.18 & 0.09 & 0.85 & -0.08 \\
\hline Researchers/scientists & 4.79 & 0.26 & 0.34 & 0.30 & 0.23 & 0.78 \\
\hline Contractors & 3.46 & 0.17 & 0.04 & 0.82 & 0.15 & -0.01 \\
\hline Fertiliser reps & 3.11 & 0.18 & 0.16 & 0.81 & 0.11 & 0.05 \\
\hline DairyNZ website & 2.99 & 0.46 & 0.57 & 0.21 & 0.07 & 0.08 \\
\hline Other websites & 2.56 & -0.07 & 0.79 & 0.11 & -0.07 & 0.01 \\
\hline Publication & 3.29 & 0.21 & 0.73 & -0.02 & 0.23 & 0.04 \\
\hline Proportion explained & & $27 \%$ & $21 \%$ & $20 \%$ & $19 \%$ & $13 \%$ \\
\hline Method & \multicolumn{6}{|c|}{ Principal component analysis, Varimax rotation } \\
\hline Sample size & \multicolumn{6}{|l|}{$\mathrm{n}=925$} \\
\hline Test for choosing three factors & \multicolumn{6}{|c|}{ Chi-square $=771.39, P$ value $<0.001$} \\
\hline Total variance explained by factors & \multicolumn{6}{|c|}{$92.64 \%$} \\
\hline \multicolumn{7}{|c|}{ Note: shaded cells have loading on factors $>0.5$, indicating the threshold value for including the attitude as a key component in the group. } \\
\hline \multicolumn{2}{|l|}{$\begin{array}{l}\text { Attitude group / } \\
\text { Information group }\end{array}$} & \multicolumn{3}{|c|}{ Pasture performance } & \multicolumn{2}{|c|}{ Experience \& information } \\
\hline Local social network & $0.21^{* *}$ & \multicolumn{3}{|c|}{$0.14^{* * *}$} & \multicolumn{2}{|r|}{$0.14^{*}$} \\
\hline Publication \& website & 0.50 & \multicolumn{3}{|c|}{-0.02} & \multicolumn{2}{|r|}{$0.15^{* \star *}$} \\
\hline Contractor \& Fertiliser reps. & -0.02 & \multicolumn{3}{|c|}{-0.01} & \multicolumn{2}{|r|}{0.01} \\
\hline Seed company & 0.01 & \multicolumn{3}{|c|}{$0.18^{\star \star}$} & \multicolumn{2}{|r|}{0.06} \\
\hline Expert & 0.08 & \multicolumn{3}{|c|}{0.09} & \multicolumn{2}{|r|}{-0.02} \\
\hline
\end{tabular}

$* * *=P<0.01,{ }^{* *}=P<0.05,{ }^{*}<<0.1$ represent statistical significance at 1,5 and $10 \%$ levels, respectively. 
correlated to local social network. The "Pasture performance" group was correlated with seed companies, while the "Experience and information" group was correlated with those who found relevant publications and websites most useful for guiding pasture renewal.

\section{Discussion}

Factor and correlation analyses were used to gain insights about adoption process around PRPs of dairy farmers in the Waikato and Bay of Plenty regions, using previous survey data.

The first question posed for this study was to gain an understanding of the drivers and barriers to the adoption of PRPs. The results showed that dairy farmers who had renewed pasture held a different attitude to pasture renewal than those who did not. The adopters may be motivated by a satisfactory pasture renewal experience while the non-adopters were disappointed having had an unsuccessful renewal experience. The non-adopter also showed lower satisfaction level with pasture performance and information accessibility compared to adopters. Intuitively, accessibility to information and pasture performance could be seen as typical drivers for adopters but barriers for non-adopters.

The diversity of farmer attitudes to pasture renewal, presents challenges to design projects and programmes that are tailored to the requirements of every farmer. The factor analysis process enabled farmers to be categorised into different groups, each with a different focus. In group one, farmers were motivated by good investment in time and money as well as suitable farm system management, while in group two, farmers were focused on pasture performance that could determine the uptake of PRPs. In group three, information and knowledge could help farmers make decisions. Hence, the flow of useful information and good com motivate the categoisation was not consistent across aloter and nonparames for pasture renewal should design facilitating strategie that fit both adopters and non-adopters requirements. This answered the second question posed for this study referring to homogeneity or otherwise of farme attitudes to pasture renewal: the attitudes of farmers were not only different between adopters armers adopters (based on the different drivers or barriers), but also within these two sets of farmers, three differen groups could be identified

Dairy farmers showed different levels of satisfaction with the information sources (the third question posed for this study) for pasture renewal. The credibility of information from local social networks was also confirmed by the correlation analysis (Table 4) with all three attitude groups correlated to a local information source. This result could provide a starting point for future supporting programmes suggesting essential information and knowledge of pasture renewal should be locally oriented and spread through farmer interactions. Information from seed companies and retailers was valued by the farmers who focused on pasture performance, while information and experience oriented farmers tend to obtain knowledge from related publication trom the adoption rate of $p$ the aloption rate of pasture renewal, future projects should include seed companies and retailers exploring and understanding farmer requirements as pasture performance was identified as a barrier to farmer adoption. Relevant information, such as the selection of suitable cultivars, could be specified and provided via publications and websites, while considering the needs of the "Experience and information orientated group" (Group 3).

\section{Conclusion}

This study contributes to the adoption literature of New Zealand by providing a quantitative framework for analysing farmer attitudes, where previous studies have mostly been qualitative. This framework could be used for other studies that focus on the adoption of other farm practices or technologies. This study identified that farmers thought highly of information experts and contacts, consistent with the results of Yang \& Sharp (2017). This indicates the importance of local connections to farmer adoption, which could be further explored in combination with regional and spatial differences in future research.

\section{ACKNOWLEDGEMENTS}

We acknowledge the Pasture Improvement Leadership Group, and in partic Gell and in Peel from Dainz from the two surveys. We would also like to thank for David Hume and Sue Zydenbos from AgResearch and two anonymous reviewers for their valuable comments.

\section{REFERENCES}

Baumgart-Getz, A.; Prokopy, L.S.; Floress, K. 2012. Why farmers adopt best management practice in the United States: A meta-analysis of the adoption literature. Journal of Environmental Management 96: 17-25.

Belgrave, B.R.; Watt, P.C.; Brock, J.L.; Wewala, S.; Sedcole, J.R. 1990. A survey of farmer knowledge and use of pasture cultivars in New Zealand. New Zealand Journal of Agricultural Research 33: 199-211.

Bergtold, J.S.; Duffy, P.A.; Hite, D.; Raper, R.L. 2012. Demographic and management factors affecting the adoption and perceived yield benefit of winter cover crops in the southeast. Journal of Agricultural and Applied Economics 44: 99-116.

Bewsell, D.; Botha, N.; Brown, M.; Fraser, T.; Wilson, J. 2008. Understanding pasture renewal in New Zealand. Report on market research for the Pasture Renewal Charitable Trust. AgResearch Ltd., New Zealand. $75 \mathrm{pp}$.

Brazendale, R.; Bryant, J. R.; Lambert, M.G.; Holmes, C.W; Fraser, TJ. 2011. Pasture persistence: how C.Wh is it worth. Grassland Reseach and Practice much is it worth.

Hansson, H.; Ferguson, R. 2011. Factors influencing the strategic decision to further develop dairy production - A study of farmers in central Sweden. Livestock Science 135: 110-123.

Knowler, D.; Bradshaw, B. 2007. Farmers' adoption of conservation agriculture: A review and synthesis of recent research. Food Policy 32: 25-48.

Pannell, D.J; Marshall, G.R ; Barr, N.; Curtis, A. Vanclay, F.; Wilkinson, R. 2006. Understanding and promoting adoption of conservation practices by rural landholders. Australian Journal of Experimental Agriculture 46: 1407-1424.

Rijswijk, K. 2013. Interactions between players in the field of pasture renewal. Proceedings of the New Zealand Grassland Association 75: 221-222.

Rijswijk, K.; Brazendale. R. 2016. Pasture renewal practices, experiences a over time Proceedings of the New Zealand Grassland Association 78: 51-56.
Rijswijk, K.; Rhodes, H. 2015. Pasture renewal in the Waikato and Bay of Plenty regions: a comparison between 2010 and 2015 farmer surveys. Client report prepared for DairyNZ by AgResearch Ltd., New Zealand. 43 pp.

Rolfe, J.; Gregg, D. 2015. Factors affecting adoption of improved management practices in the pastoral industry in Great Barrier Reef catchments. Journal of Environmental Management 157: 182-193.

Schmitt, T.A.; Sass, D.A. 2011. Rotation criteria and hypothesis testing for exploratory factor analysis: Implications for factor pattern loadings and interfactor correlations. Educational and Psychological Measurement 71: 95-113.

Stevens, D.R.; Knowles, I. 2011. Identifying the need for pasture renewal and valuing the contribution of renewal on a dairy farm-Telford Dairy, a case study. Grassland Research and Practice Series 15: 211216.

Tozer, K.N.; Rennie, G.M.; King, W.M.; Mapp, N.R. Aalders, L.T.; Bell, N.L.; Wilson, D.J.; Cameron, C.A.; Greenfield, R.M. 2015. Pasture renewal on Bay of Plenty and Waikato dairy farms: impacts on pasture performance post-establishment. New Zealand Journal of Agricultural Research 58: 241258

Yang, W.; Sharp, B. 2017. Spatial dependence and determinants of dairy farmers' adoption of best management practices for water protection in New Zealand. Environmental Management 59: 594-603. 